\title{
Why Manufacturers are Less Powerful than Retailers in Trade Circles? A Case Study of Wal-Mart Retailing Business
}

\section{Shabbir MS*}

Centre of Professional Excellence (CPE), Blue Area, Islamabad, Pakistan

\begin{abstract}
This paper investigates that from last several years, it became a question mark for the literature of academic and trade circles, why manufacturers are less powerful as compared to retailers. Our study provides a fresh fuel in the existing fire over the United States largest retailing corporation. However, our research provides a new dimension through innovative strategies and theories adopted by Wal-Mart and how retailers become more powerful. For this purpose, we take Wal-Mart as a case study in order to investigate several quarries. What are the reasons which make Wal-Mart so successful, unique, mergence and acquisition innovative capabilities? It also highlights the literary work done by historians on Wal-Mart and to examine the progress and different strategies of Wal-Mart in term of its success in retailing business. It is observed that most of expansion of Wal-Mart Inc. was through joint ventures; however in some countries such as Germany and Canada, it was by acquisition. Moreover, Globalization had a positive effect on Wal-Mart's success and supply chain management system played a major role in its business growth and making it a market leader.
\end{abstract}

Keywords: Wal-Mart; Trade circles; Innovative strategies; Academic literature; Retailing business

\section{Introduction}

There was a long debate how retailers became more powerful than manufactures, however some studies [1-4] suggested that retailors got several benefits from manufacturers such as allowance of slotting, discount of bulk purchase and trade deals and they also took extra discount from manufacturers which increased the market power of retailors and surge their profit also. The answer of the academic literature is controversial whereas, they suggested that such a transference can occurred. While some researchers are not still satisfied such kind of shift can be exist and they made theoretical challenges for themselves [5-7].

The history of Wal-Mart's started from 1930s when a need for discount retailing store arose the major reason for this was Great Depression of 1930. After World War II the concept of grocery super stores got popularity due to low rates, easy access, long working time and colorful advertisement. In 1930s, only few discount super stores were working in United States mainly located in the office building in New York and other major cities. After World War II due to high inflation served a base for discount retailing and Sam Walton noticed the opportunity and availed it (Wong, 2009). In 1940 Sam Walton was running a variety of stores in New York a momentous idea come in to his mind why don't I should bargain from supplier and get extra money and sell goods to supplier at same price in that way to earn more profit [8]. Wal-Mart is a United States public corporation that runs a chain of large discount departmental stores and warehouse stores that operates in various formats around the world. It was found in 1962 by Sam Walton and its Headquartered located is in Bentonville and Arkansas USA [9].

However, the data which reflects fiscal period of five years from 2009 to 2013 provided a snapshot of Wall Mart's performance, where it operated more than 10,700 retail units, approximately 245 and $75 \%$ customers work in their stores and operation Management joined hourly associated to Wall Mart's in United States and 27 countries across the world respectively. It also increased respectively $59 \%$ and $123 \%$ in earning per share and cash flow, which effected positively to their shareholders by $\$ 60$ billion in term of dividend and repurchase of shares. Free cash flow is a non-GAAP measure. Net cash provided by operating activities of continuing operations is the closest GAAP measure to free cash flow. Reconciliations and other information regarding free cash flow and its closest GAAP measure can be found in the Management's Discussion and Analysis of Financial Condition and Results of Operations included in this Annual Report and on our website at http://www.stock.walmart.com [10].

When it comes to our operating segments, Wall mart U.S. is as strong as it has ever been. Last year, we opened our $4,000^{\text {th }}$ U.S. location and added more than $\$ 10$ billion in net sales, including $\$ 4.7$ billion in sales growth. We had positive performance and grew market share in a number of our largest categories. Wall Mart International continues to be the growth engine for our company, contributing nearly 30 percent of consolidated net sales, while adding 19 million square feet of new retail space [11].

However, top management of Wal-Mart gave a new strategy of low price and expansion in its products to increase their customers. Wal-Mart Stores emerged to rural Arkansan in 1970s to reshape itself in world's largest economy. Its co-founder, Sam Walton, taught United States to demand for low cost products having best quality or discount store concept. With the passage of time, this company boosts United States Overall productivity, decreased the inflation rate and strengthened the buying power for millions of people of United States. After achieving their desire targets in United States, the top management of company decided to enter in to Asian countries, and

${ }^{*}$ Corresponding author: Shabbir MS, Faculty, Centre of Professional Excellence (CPE), Blue Area, Islamabad, Pakistan, Tel: 0343-6656850; E-mail: mshahzad786.pk11@gmail.com

Received August 06, 2015; Accepted August 14, 2015; Published August 21 2015

Citation: Shabbir MS (2015) Why Manufacturers are Less Powerful than Retailers in Trade Circles? A Case Study of Wal-Mart Retailing Business. Bus Eco J 6: 177 doi:10.4172/2151-6219.1000177

Copyright: () 2015 Shabbir MS. This is an open-access article distributed unde the terms of the Creative Commons Attribution License, which permits unrestricted use, distribution, and reproduction in any medium, provided the original author and source are credited. 
then the company introduced their production with different strategy such as small stores inside the streets and large stores on main streets and this affect was stable on Asian markets [12].

Wal-Mart has 158 distribution centers all across the world. Moreover, Wal-Mart has largest distribution operation in the world. Their logistic setup has a fleet of 6500 tractors, 55000 trailers and more than 7000 drivers. Their regional distribution centers have 12 miles of conveyor belts which can have hundreds of thousands of cases through facility each day [13]. The major activities of Wal-Mart's are

- $\quad$ Purchasing the goods

- Deliver that goods

- $\quad$ Cost control over goods

The other different types of activities were performed for fulfilling the requirement of specific customer [9]. Wal-Mart has a competitive edge in its inventory control procedure, logistics system, and distribution network [14]. The ability to move the goods from one place to others were efficiently and speedy without any disruption result in a great cost reduction which Wal-Mart's achieve. Wal-Mart has exact time information of their products in the stores shelves and when additional products required filling the shelves [15]. The resources of Wal-Mart were consisting on main three categories. First of all, the physical resources which are owned and controlled by the management? Second its human resources, experienced managers, stores managers and logistic staff, and finally the company culture heritage Wal-Mart culture is based on restless effort and focus on constant self-improvement, loyalty and discipline [16].

Key relation of partnership in Wal-Mart was buyer-supplier relationship, in which suppliers were considered as close partners of Wal-Mart. They are also part of the value chain process of each other and it delivered suppliers the chance of accessing itself to a large market. However, it made able the suppliers, who want to take advantages of its broad market, to keep their prices at low cost and the suppliers able to control of their own business and negotiation benefits from Wal-Mart [17]. Wal-Mart customers can be divided into three groups: "brand aspirations", people with low incomes who are obsessed with brand; "price-sensitive effluents" wealthier shoppers who love deals; and finally "value-price shoppers" who like low prices and cannot afford much more [18].

\section{Wal-Mart's business model}

Business model describes the organization process of delivers, captures and create value of their goods through a flow chat procedure [19]. Although Elman and Hughes [4] consider four key elements of the business model, the analysis of Wal-Mart's Business Model is given by Osterwalder and Pigneur [19] consist of nine building blocks (Figure 1).

Wal-Mart revenue that generated from its different customer segments are basically come from retail business, such as music downloading, fixed menu pricing. Wal-Mart also earn revenue from selling its own brand, produces by others to cover a segment not cover by other suppliers. Moreover, it takes advantage of selling goods before paying to its suppliers. In year 2012, Wal-Mart delivered a strong financial performance with huge profit. Net sales increased by $5.9 \%$ and reach to $\$ 443.9$ billion, and the consolidated operating income grew by $4 \%$ to $\$ 26.6$ billion. The diluted earnings per share from Wal-Mart's continued operation were $\$ 4.54$ per share, from $\$ 4.18$ in the previous year. However, Wal-Mart's strong financial position which, defines best

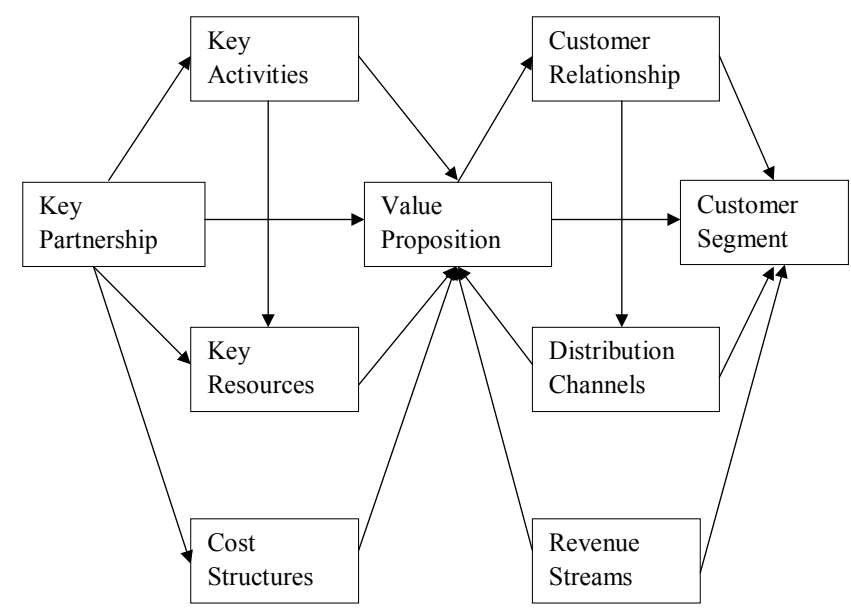

Figure 1: Osterwalder's 9 point decomposition of a Business Model. Source: (Chesbrough, 2010).

their ability to grow. In 2012 Wal-Mart's added 52.2 million square feet through 1,160 additional units previous, including acquisitions in the U.K. and South Africa [20]. The operating ratios of the Wal-Mart five year is shown at Appendix-I, which showed in Wal-Mart's financial performance.

\section{Research question}

How retailing business in developing countries can compete with Wal-Mart innovative strategies?

\section{Research objectives}

- To explore the factors behind the success of Wal-Mart.

- To study the effect of technological advancement on Wal-Mart operations.

- To analyze the effects of globalization on Wal-Mart growth.

\section{Literature Review}

Wal-Mart competitors are generally divided in to two parts Local competitors and foreign competitors. Wal-Mart is giving tough competition to its competitors like Circuit City, Toys R, Home Depot etc and generally put pressure on them to increase the market responsiveness by taking several action in competition to Wal-Mart [21]. Wal-Mart creates a tough competition for its competitors and it was not easy for them to compete with Wal-Mart. Every new Wal-Mart stored decreases local competition, market share and profit margins, and result some businesses to close [22].

According to Warburg (2002) studied by Curie and Jain prices of Wal-Mart is in average of $14 \%$ lowest than their competitors [23]. Wal-Mart has 23 miles of retail selling space in the U.S., where 5,500 of its stores consist of $70 \%$ of its total which located in United States. Its annual revenues of 2004 were just over $\$ 288$ billion (Revell, 2005). Wal-Mart is the top US sellers and its sales mainly consist of groceries, music, electronics etc. his company has the largest employees in the United States in private sector with 1.3 million of employees. In 2004 it singly handled $6.5 \%$ of total U.S retail sales. Almost 12 million of United States shop from Wal-Mart in every week and in a survey it showed that $84 \%$ of United States has done shopping from Wal-Mart in a year 2005 [24]. 
From the global perspective Wal-Mart is the largest retailing store network in the world. The sales of Wal-Mart is higher than the combines sales of three of its retailing store competitors Carrefour (France), Home Depot (United States), and Metro (Germany). WalMart has been a global leader in retailing business due to many ways, (i) its investment in information technology, (ii) its transformation of supply chain system in to a relationship with its suppliers and customers by establishing its private-label brand and directly purchasing from overseas producers to reduce cost and achieving its policy of "low cost always" another advantage it provides is "one-stop shopping" which make difference from its competitors [14].

Wal-Mart locates its stores in different places, where they consider being profitable after detail study. It includes the possible factors, information about demand for product and cost related to it, the competitive environment and how the competition will be affected after Wal-Mart's entry. Holmes [25] and Jia [22] discuss various demographic factors related to Wal-Mart entry in the market, such as the density and the size of the population, age and income distribution. Now we will study the different strategies due to which the Wal-Marts have maintained its competitive advantage in local and foreign markets.

The mission statement of the Wal-Marts is "Low prices always". They are following their unique mission statement and focus on the business to achieve that mission their low price slogan is good for Wal-Mart as it is paying them even good for shoppers and especially lower income people. Wal-Mart generated savings for customers through cost reduction strategies. One such savings method was done by removing deodorants from boxes. Savings were realized by weight savings in shipping, the purchases of boxes, design and printing for the box. Each box cost approximately five cents. This savings was divided between Wal-Mart and the deodorant companies [26]. Wal-Mart affect the local cost of living standard in two ways (1) the direct effect of the retailer own prices (2) indirect effects due to the retailer competiveness on other merchants (Freeman et al., 2011).

Globalization is another effective and innovative strategy used by the Wal-Mart's. Retail system is becoming global in these days due to its different characteristics such as, new strategic objectives and new capabilities. It is noted that consumers is well- aware and knowledgeable about their needs and wants, more demanding of products and also more search for its required products, values and services from the retailers [27]. Wal-Mart's international stores supply chain is spread around the world such as Canada, Brazil, Mexico, and Costa Rica. Wal-Mart's International stores represent about 45 percent of its total retail outlets [28]. The current goal of Wal-Mart is to increase its international business from its current level of 20-33 of its total revenue which estimated roughly 103 billion by purchasing major interest in 415 retail stores in Latin America and this strategy is followed by WalMarts around the globe [29,30].

Information technology is another Wal-Mart's innovative strategy, which plays a major role in Wal-Mart's success. Wal-Mart becomes a leader in technological business process and maintaining the world largest private sector data ware house. However, this data has used mainly by the managers along with suppliers who give access to it for effectively utilizing the coordinated efforts among themselves. WalMart was the first company who build the world first largest satellite communication system. This company is using such data which enabled supply chain coordination process known as collaborative planning, forecasting and replenishment (CPFR) which help them to make coordinated business plans.
Wal-Mart was the first company who used barcode and RFID technology in their store E-recruiting and automated testing system for candidates they got skilled workers all the time. Wal-Mart is not only performing in traditional retailing system but also leading in e-retailing. However, Walmart.com was founded in year 2000 as a joint venture of Wal-Mart Stores and Accel Partners, a leading venture capital firm of that time in Silicon Valley. Walmart.com Inc. is one of the largest e-retailing companies in the world. Walmart.com offers 1.5 million; easy-to-use music downloads digital one-hour photo services, and an adding on innovative strategies to position itself as an online leader [31].

In supply chain procedure Wal-Mart is excellent in working. Wal-Mart slogan is "Low Cost" and they are maintaining that slogan by understanding the importance of controlling cost through supply chain procedure due to this reason Wal-Mart is more focus on pull and demand base supply system instead of traditional push and supply based system. However, the difference in both of them, in pull and demand base system customer determine the requirement of goods while in push and supply system manufacture determine the production requirement and then floated to market [32]. It is a general phenomenon, to every success there are some failures. WalMart's was very successful in those countries around the United States but it became unable to get much success in countries like Germany, Korea and India .One of the reason that these countries customer do not accept Wal-Mart format [33]. Wal-Mart entry in to Pakistan will be the great advantage to Pakistan economy in terms of foreign direct investment (FDI), reducing inflation and job opportunity but a threat to small retailers.

\section{Theoretical Frame Work}

From the literature reviews we understand that Wal-Mart has different innovative strategies mentioned at independent variables have result in increase of sales and revenue of Wal-Mart (Figure 2).

\section{Theories applied}

From literature review it seems that Wal-Mart is following different theories for growth of their business and increase in sales. The theories manly use are (i) Dunning's theory of the eclectic firm for international expansion (ii) Theory of creative destruction (iii) Theory of networking effect. Dunning's (1981) theory of eclectic firm approach has been widely used for determine FDI and international expansion

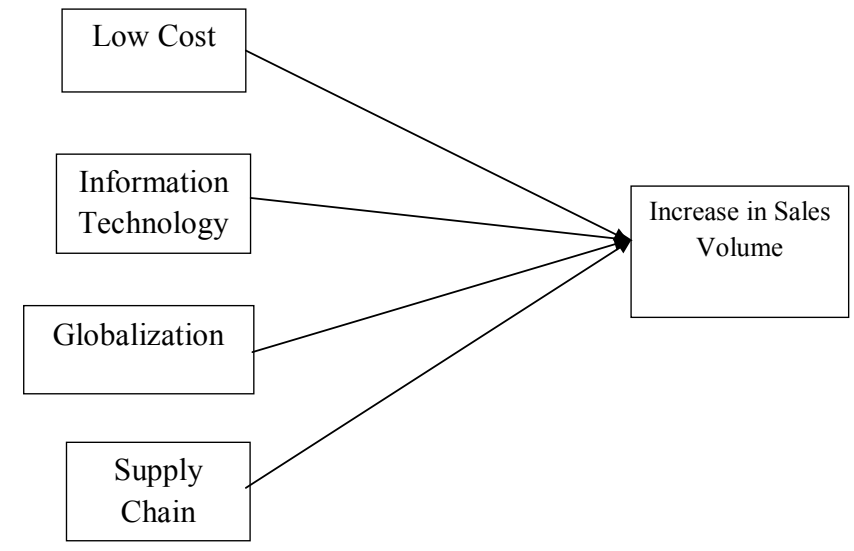

Figure 2: Different innovative strategies mentioned at independent variables have result in increase of sales and revenue of Wal-Mart. 
.This theory is applied by Wal-Mart when the company is entering in Germany, Korea and India [33]. The Theory of creative destruction was used by Wal-Mart when the company moves from bar code system to RFID technology. The theory of networking effect is best applied by Wal-Mart in terms of Wallmart.net and CPFR system.

\section{Conclusion and Recommendations}

Based on the above literature review and study following is the result of this study. Low Cost retailing has a positive effect on WalMart's growth and success. Information Technology innovation plays a significant role on the success of Wal-Mart's. Globalization has a positive effect on Wal-Mart's success and supply chain management system play a major role in the growth of Wal-Mart's and making it a market leader in retailing business.

On the basis of above study I recommended the following things. No doubt Wal-Mart's strategies are very much effective for United States and its neighborhood countries and the company could not get much success in countries like Germany, Korea and India. However, Wal-Mart's should focus on culture issues rather than low cost strategy. For better result Wal-Mart's should also focus on making strategic alliance for geographic dispersed countries. For developing countries like Pakistan disparately need such kind of companies, so Wal-Mart's entry will lead to prosperity but their motive should not be hostile takeover of other retailing store and making monopoly in the region.

The future area relating to this paper is the RFID technology implications, development and commercial utilization in stores of WalMart and for supply chain process and the use of CPFR technology its benefit and how much it is important for giant retailing super store chains etc. Secondly the effect of e-retailing should be analyzed and how it is affecting the traditional retailing process and future prospects of Wallmart.net in this respect.

\section{References}

1. Bowman RJ (1997) Should You Just Say No to Wal-Mart? Distribution 96: 52-54.

2. Buzzell RD, Quelch JA, Salmon WJ (1990) The Costly Bargain of Trade Promotion. Harvard Business Review 68: 141-149.

3. Elman D, Hughes B (1988) How much are Deals Driving BM/HBA? Supermarket Business.

4. Johnson WC (1988) Sales Promotion: It's Come Down to Push Marketing Marketing News.

5. Kim SY, Staelin R (1998) Retail Power: Is it an Illusion? Working paper, Fuqua School of Business, Duke University.

6. Lariviere MA, Padmanabhan V (1997) Slotting Allowances and New Product Introductions. Marketing Science 16: 112-128.

7. Sullivan MW (1997) Slotting Allowances and the Market for New Products. Journal of Law and Economics 40: 461-493.

8. Frank TA (2006) Everyday Low Vices: How much should we hate Wal-Mart? Washington Monthly.

9. Yunsheng LI (2011) Wal-Mart Business Model Study. IJAEBM Journal 1: 1-5.

10. http://www.stock.walmart.com

11. Wall-Mart's Annual Report, 2013.

12. McWilliams G (2007) Wall Street Journal 3: 1-5.

13. http://www.corporate.walmart.com
14. Basker E (2007) The Causes and Consequences of Wal-Mart's Growth Economic Perspectives 21: 177-198.

15. Tierney S (2004) The global reach of Wal-Mart. Supply Chain Europe 13: 40-41.

16. Fishman C (2006) The Wal-Mart effect: how the world's most powerful company really works and how it's transforming the American economy. Penguin Press, New York

17. Parnell JA, Lester DL (2008) Competitive Strategy and the Wal-Mart Threat Positioning for survival and Success. SAM Advanced Management Journal 73: 14

18. Barbaro M (2007) It's Not Only About Price at Wal-Mart. The New York Times Company.

19. Osterwalder A, Pigneur Y (2010) Business Model Generation. John Wiley \& Sons. Hoboken.

20. Wall-Mart's Annual Report, 2012.

21. Swinyard WR (1997) Retailing trends in the USA: competition, consumers, technology and the economy. International Journal of Retail \& Distribution Management 25: 244-255.

22. Jia P (2008) What Happens When Wal-Mart Comes to Town: An Empirical Analysis of the Discount Industry. Econometrica 76: 1263-1316.

23. Bianco, Zellner (2003) Is Wal-Mart too powerful. Business Week.

24. Pew Research Center for the People and the Press (2005) Wal-Mart: A Good Place to Shop but Some Critics Too.

25. Holmes T (2001) Bar Codes Lead to Frequent Deliveries and Superstores RAND Journal of Economics 32: 708-725

26. Pittman J (2007) The Wal-Marts Effect: A theological Analysis.

27. Maharajh L, Heitmeyer J (2005) Factors that impact United States retailers expansion into the international market place. Journal of Fashion Marketing and Management 9: 144-155.

28. International Operations Fact Sheet (2007).

29. Longo D (2005) Wal-Mart's on its way to becoming first trillion dollar corporation. Retail Merchandiser 45: 7.

30. Ramshad E (2006) South Korea, E-Mart is no Wal-Mart, s which is precisely why locals love it. Wall Street Journal

31. Noriega D, Sameer Kumar, Eideon J (2012) International Journal of Productivity and Performance Management 61: 805-830.

32. Blanchard C, Clark L.com (2008) Adding values to service providers: Benchmarking Wal-Mart Benchmarking Journal 15: 166-177.

33. Halepete J, Seshadri Lyer KV, Park SC (2008) Wal-Mart in India: a success or failure? International Journal of Retail \& Distribution Management 36: 701-713. 